\title{
NOTES ON THE EARLY STAGES OF THE COMMENSAL POLYNOID ACHOLOE ASTERICOLA (DELLE CHIAJE)
}

\author{
By Demorest Davenport \\ University of California, Santa Barbara College
}

(Text-fig. I)

Little is known about the development of polynoids. A large number of unidentifiable polynoid trochophores and nectochaetes have been described by Nolte (1936) and others. As Thorson (1946) states, Nolte has done little to clear up the confusion that prevails in this group and his 'numerous figures, all more or less incorrect, and accordingly difficult to recognize, merely serve to further obscure our picture'.

A search of the literature with the aid of Hartman (I95I) has so far revealed only one clearly identifiable member of the family whose early larval stages have been described. Sars $(\mathrm{I} 845 a, b)$, making some of the earliest observations on polychaete life histories, described under the name Polynoë cirrata Fab. the early stages of Harmothoë imbricata (L.). Further studies in some detail on this or a closely allied species were made in turn by Müller (I85I), McIntosh (I900) and Izuka (I9I2). The certainty of identification of the parent in this case stemmed from the fact that the early stages, with the exception of those studied by Müller, were not taken in the plankton but were observed attached to the brooding parent after release from it. In this polynoid the eggs are carried in large masses beneath the elytra, and larvae leave the parent as actively swimming trochophores. This method of carrying the young has also been observed in H. imbricata by Saemundsson (I9I8) in Greenland and by M. Pettibone (personal communication) in Puget Sound. Desor (1857) quotes the observations of Sars on the brooding habit, and describes the release of trochophores by Polynoë squamata (=Lepidonotus squamatus L. ?) on the New England coast. He does not make clear whether the form he studied also brooded its eggs beneath the elytra. However, Fauvel (I9I6) observed brooding in Polynoë antarctica Kinberg, from the Falklands, and MacGinitie \& MacGinitie (1949) in Halosydna brevisetosa Kinberg from the eastern Pacific. Thus, brooding in polynoids may be commoner than has been suspected.

From October of 1952 until July of 1953 , while the author held a Guggenheim Fellowship at the Plymouth Laboratory and was engaged in making studies (Davenport, I953 $a, b$ ) of the response behaviour of commensal annelids 
to their hosts, repeated efforts were made to bring to metamorphosis and settlement the young of the polynoid Acholoë astericola (Delle Chiaje), commensal with the starfish Astropecten irregularis (Pennant). Although in a number of cultures it was possible to carry the larvae through IO-I2 days of development, none were taken beyond the trochophore stage; critical experiments to determine the manner of settlement and the method of hostcolonization were never possible. In view, however, of the general lack of information concerning polynoid development and the certainty of identification of the young of only one other polynoid species at the present time, it has seemed advisable to describe the stages observed, in spite of failure in bringing the life history to completion.

At no time from October to July was natural spawning observed, in spite of the fact that Acholoe were brought into the laboratory on their host starfish continuously during this time and kept under a variety of conditions. Eggs and sperms were obtained by cutting open worms, and fertilizations were made in filtered 'outside' sea water. Dishes were kept at the temperatures of the laboratory circulation $\left(\mathrm{I} 4-\mathrm{I} 6^{\circ} \mathrm{C}\right.$.). Cultures were also placed in large plunger jars. Although trochophores were observed to feed on pure cultures of the flagellates Dicrateria inornata Parke and Isochrysis galbana Parke, after an average of Io days all dropped to the bottom, became inactive and broke up.

The sequence of events to be described was observed with fertilizations made in the month of November, at which time in any collection the number of adult worms with active sperms or fully formed eggs was low. During the winter the number of such individuals in any collection approached nil. During the months of April and May apparent fertility increased until in July almost all individuals opened had active sperms or fully formed eggs. Thus, it would appear that Acholoe is a midsummer or autumn spawner, at least at the latitude of Plymouth.

Eggs freshly removed from the body cavity were pinkish in reflected light and slightly oval, the long dimension averaging approximately $85 \mu$, with a membrane approximately I. $5 \mu$ in thickness. Very shortly after fertilization the membrane separated from the eggs and there often appeared a slightly raised area or 'bubble' at one pole. From I2 to I4 hr. after fertilization larvae were actively spinning and the beginning of ciliary bands had appeared. The long dimension had by this time increased to about $97 \mu$.

By the end of $48 \mathrm{hr}$. many of the oval prototrochophores (Fig. IA) were actively swimming, rotating on their long axes and moving in the direction of the apical tuft. Their long dimension at this time was approximately $100 \mu$. The apical tuft was composed of fifteen or more very long cilia fully two-thirds the length of the larva $(65 \mu)$, while the clearly evident prototroch consisted of a single band of cilia which were approximately $20 \mu$ long. An opaque central area indicated the beginning of the digestive tract. 
By the end of $72 \mathrm{hr}$. the larvae had considerably advanced, although there was little change in size. Most had developed a single red eye-spot, though in some two had appeared. There was some reduction in size of the apical tuft,

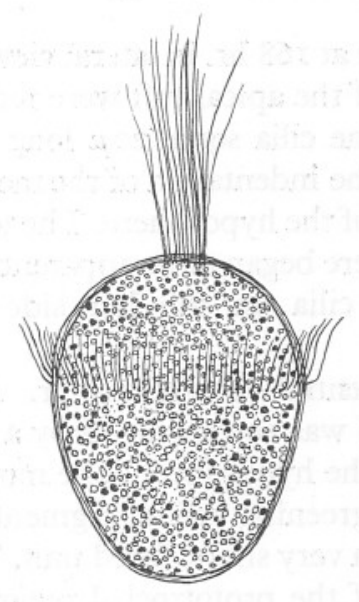

A

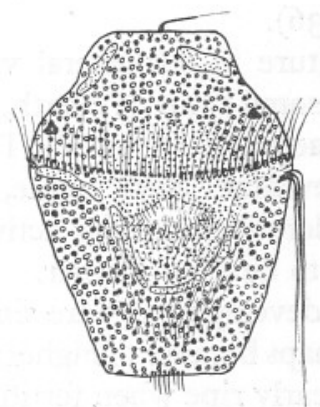

C

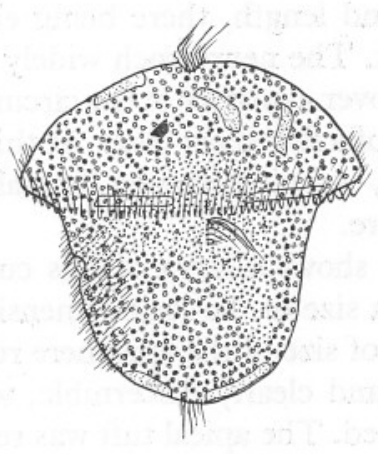

B

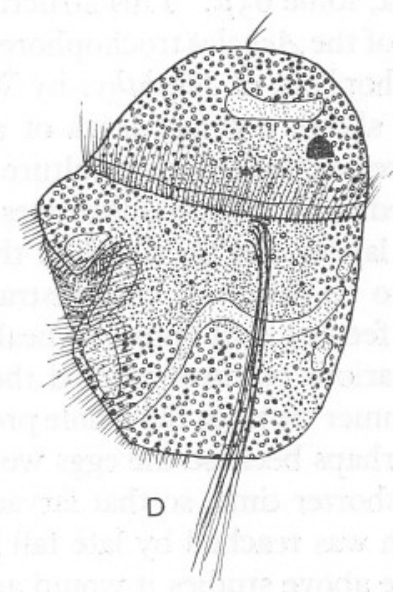

Fig. I. Early stages of Acholoë astericola (Delle Chiaje). A, prototrochophore at $48 \mathrm{hr}$; $\mathrm{B}$, trochophore at $\mathrm{I} 68 \mathrm{hr}$., showing beginning of left lateral tuft; C, trochophore at $2 \mathrm{I} 6 \mathrm{hr}$. in ventral view; $\mathrm{D}, 9$-day trochophore of July culture in left lateral view.

still a single-rowed prototroch and as yet no other groups of cilia. Rather large yellowish green pigment bodies had begun to make their appearance in the apical and prototrochal region and in the hyposphere.

By the fourth day one could discern stomach and intestine, in which there was ciliary activity. A small clump of cilia marked the beginnings of the telotroch. Most individuals possessed two eye-spots. At this time the larvae 
had begun to assume the typical shape of the early trochophore in which the episphere appears to overhang the hyposphere.

By the sixth day little change had occurred, but one could discern a definite ventral ciliary band or neurotroch.

Fig. I B shows a trochophore of this culture at I68 hr. in lateral view. There had been little increase in length. The cilia of the apical tuft were reduced in number and length, there being eight or nine cilia some $20 \mu$ long sunk in a small pit. The neurotroch widely covered the indentation of the mouth and extended over a quarter of the circumference of the hyposphere. The telotroch consisted of a few short cilia. At this stage there began to be apparent a short, comb-like, scimitar-shaped lateral tuft of cilia on the left side of the trochophore.

Fig. IC shows a larva of this culture in ventral view at $2 \mathrm{I} 6 \mathrm{hr}$. A slight increase in size of the long dimension ( $107 \mu$ ) was accompanied by a relative reduction of size of the episphere relative to the hyposphere. The mouth was extensive and clearly discernible, while the greenish yellow pigment bodies were marked. The apical tuft was reduced to a very short, fused unit. The left lateral tuft, hanging down from the 'belt' of the prototrochal region like a scabbard, had increased greatly in length until it was fully two-thirds the length of the larva, some $63 \mu$. This structure is one of the most marked diagnostic characters of the Acholoë trochophore; such a structure has also been described in the trochophore of Nephthys by Wilson (1936).

Fig. ID shows a 9-day larva of a July culture in left lateral view. The trochophores of this summer culture averaged some $\mathrm{I} 30 \mu$ in length, although they showed no structural differences from larvae raised in the fall. The extent of the oral lappet and the depth of the pit are evident. Such larvae, the most advanced to be observed, demonstrated considerable muscular activity. All, in spite of feeding and apparent health, failed to develop further.

In the various cultures studied the steps in development were similar, but in mid-summer cultures the whole process, perhaps because of higher temperatures or perhaps because the eggs were more nearly ripe when fertilized, took place in a shorter time, so that larvae took no more than 3 days to reach the stage which was reached by late fall larvae in not less than $7-9$ days.

From the above studies it would appear that Acholoë has an early development that allows the organism to be widely dispersed by ocean currents, and in this respect, in spite of its being an obligate commensal as far as is known, is similar to other polynoids. The problems of settlement and 'colonization' of host remain unsolved. No young worms smaller than $0.5 \mathrm{~cm}$. have ever been observed on Astropecten. Do the larvae metamorphose on the correct substrate and later find the host? It is possible that if eggs and sperm can be had from naturally spawning adults, and if problems of temperature and feeding can be met, such questions may ultimately be answered. 


\section{SUMMARY}

The development of the larva of Acholoë astericola (Delle Chiaje), a commensal of Astropecten irregularis, is described up to the late trochophore stage. The larva of only one other identifiable polynoid worm had previously been described.

\section{REFERENCES}

DAvenport, D., I953a. Studies in the physiology of commensalism. III. The polynoid genera Acholoë, Gattyana, and Lepidasthenia. F. Mar. biol. Ass. U.K., Vol. 32, pp. I6I-73.

- 1953b. Studies in the physiology of commensalism. IV. The polynoid genera Polynoë, Lepidasthenia and Harmothoë. F. Mar. biol. Ass. U.K., Vol. 32, pp. $273-88$.

DESOR, E., I857. On the embryology of Nemertes, with an appendix on the embryonic development of Polynö̈, and remarks upon the embryology of marine worms in general. F. Boston Soc. nat. Hist., Vol. 6, pp. I-I8.

Fauvel, P., I9I6. Annélides Polychètes des Iles Falkland recueillies par M. Rupert Vallentin Esq. (I902-1910). Arch. Zool. exp. gén., T. 55, pp. 4I7-82.

HARTMAN, O. I95I. Literature of the polychaetous annelids. Vol. I. Bibliography. Los Angeles.

IzukA, A., I9I2. The errantiate Polychaeta of Japan. F. Coll. Sci. Tokyo, Vol. 30, Art. 2, pp. I-262.

MacGinitie, G. E. \& MacGinitie, N. 1949. Natural History of Marine Animals. New York.

McIntosh, W. C., 1900. A Monograph of the British Marine Annelids, Vol. I, part 2, pp. 2I7-444. Ray Society, London.

MÜlLER, M., I85I. Ueber die Entwickelung und Metamorphose der Polynoën. Müllers Arch. Anat. Physiol., Berlin, pp. 323-37.

Nolte, W., 1936. Annelidlarven. Nord. Plankt. Lief. 23, pp. 59-169.

SAEMUNDSson, B., I918. Bidrag til Kundskaben om Islands polychaete Børsteorme (Annulata Polychaeta Islandiae). Vid. Medd. dansk. naturh. Foren. Kbh., 69, pp. 165-24I.

SARS, M., I845a. Zur Entwickelung der Anneliden. Wiegmann's Arch. Naturgesch., Jahr. II, Bd. I, pp. II-I9.

- $1845 b$. On the Development of the Annelides. (Transl. of above). Ann. Mag. nat. Hist., Ser. I, Vol. I6, pp. 183-8.

Thorson, G., 1946. Reproduction and larval development of Danish marine bottom invertebrates with special reference to the planktonic larvae in the Sound (Øresund). Medd. Komm. Havundersøg. Kbh., Ser. Plankton, Bd. 4, No. I, 523 pp.

WILson, D. P., I936. Notes on the early stages of two polychaetes, Nephthys hombergi Lamarck and Pectinaria koreni Malmgren. F. Mar. biol. Ass. U.K., Vol. 21, pp. 305-ro. 